\title{
Streptomyces hokutonensis sp. nov., a novel actinomycete isolated from the strawberry root rhizosphere
}

\author{
Hideki Yamamura ${ }^{1}$, Haruna Ashizawa ${ }^{1}$, Moriyuki Hamada ${ }^{2}$, Akira Hosoyama ${ }^{2}$, Hisayuki Komaki ${ }^{2}$, \\ Misa Otoguro ${ }^{2}$, Tomohiko Tamura ${ }^{2}$, Yukikazu Hayashi ${ }^{1}$, Youji Nakagawa ${ }^{1}$, Takashi Ohtsuki ${ }^{1}$, \\ Nobuyuki Fujita ${ }^{2}$, Sadaharu Ui ${ }^{1}$ and Masayuki Hayakawa ${ }^{1}$
}

A polyphasic approach was used to determine the taxonomic position of actinomycete strain R1-NS-10 ${ }^{\top}$, which was isolated from a sample of strawberry root rhizosphere obtained from Hokuto, Yamanashi, Japan. Strain R1-NS-10 $10^{\top}$ was Gram-staining-positive and aerobic, and formed brownish-white aerial mycelia and grayish-brown substrate mycelia on ISP-2 medium. The strain grew in the presence of $0-5 \%(\mathrm{w} / \mathrm{v}) \mathrm{NaCl}$ and optimally grew without $\mathrm{NaCl}$. The strain grew at $\mathrm{pH} 5-8$, and the optimum for growth was $\mathrm{pH}$ 7. The optimal growth temperature was $30^{\circ} \mathrm{C}$, but the strain grew at $5-37^{\circ} \mathrm{C}$. Whole-cell hydrolysates of strain R1-NS-10 $10^{\top}$ contained $A_{2} \mathrm{pm}$, galactose, mannose and rhamnose. The predominant menaquinones were MK-9 $\left(\mathrm{H}_{6}\right)$ and MK-9 $\left(\mathrm{H}_{8}\right)$. The major cellular fatty acids were anteiso- $\mathrm{C}_{15: 0}$ and iso- $\mathrm{C}_{16: 0}$. Comparative $16 \mathrm{~S}$ rRNA gene sequence analysis revealed that strain R1-NS-10 $10^{\top}$ was most closely related to Streptomyces prunicolor NBRC $13075^{\top}(99.4 \%)$. The draft genome sequences of both strains were determined for characterization of genome sequence-related parameters such as average nucleotide identity (ANI) and the diversity of secondary metabolite biosynthetic gene clusters. DNA-DNA hybridization (DDH) and ANI values for both strains were below the species delineation cutoff, and differences in physiological and biochemical characteristics differentiated strain R1-NS-10 $10^{\top}$ from its closest phylogenetic relative. On the basis of these data, we propose that strain R1-NS-10 $0^{\top}\left(=\right.$ NBRC $108812^{\top}=$ KCTC $\left.29186^{\top}\right)$ should be classified as the type strain of a novel Streptomyces species named Streptomyces hokutonensis sp. nov. The Journal of Antibiotics (2014) 67, 465-470; doi:10.1038/ja.2014.20; published online 2 April 2014

Keywords: polyphasic taxonomy; strawberry root rhizosphere; Streptomyces

\section{INTRODUCTION}

The genus Streptomyces is characterized by the presence of LL-diaminopimelic acid $\left(\mathrm{A}_{2} \mathrm{pm}\right)$ in the cell-wall peptidoglycan, a large amount of saturated iso- and anteiso-branched fatty acids, and nine isoprene units as the predominant menaquinones. ${ }^{1}$ As of this writing, the genus Streptomyces consists of 640 species with validly published names. ${ }^{2}$ Since the discovery of streptomycin from Streptomyces griseus, various pharmaceutically important drugs have been discovered from the genus Streptomyces. ${ }^{3-6}$ Given the importance of the Streptomyces as a source of pharmaceuticals, exploration of the natural environment with the aim of discovering novel species in this genus is important. In addition, characterization of the physiological and genotypic features of members of this genus will broaden our understanding of the behavior of these organisms in various ecosystems.
Recent progress in genome sequencing methods has led to the discovery that the Streptomyces have the potential to produce a diverse array of secondary metabolites. ${ }^{7-9}$ Furthermore, genomic data have given rise to new taxonomic parameters that can be used for species classification, such as the average nucleotide identity (ANI) of common genes and the percentage of conserved DNA. Comparison of DNA-DNA hybridization (DDH) and ANI values has shown that an ANI of 95-96\% correlates well with the current bacterial species boundary of $70 \%$ DDH similarity. ${ }^{10-12}$

Streptomyces spp. are distributed in a variety of habitats, such as soil, freshwater and marine environments, as well as in association with lichens. ${ }^{13,14}$ Streptomyces spp. are particularly abundant in the soil and rhizosphere. Streptomyces spp. known as plant-growthpromoting rhizobacteria capable of producing auxin and/or siderophores have been isolated from the rhizosphere. ${ }^{15,16}$

${ }^{1}$ Division of Applied Biological Sciences, Interdisciplinary Graduate School of Medicine and Engineering, University of Yamanashi, Kofu, Japan and ${ }^{2}$ Biological Resource Center, National Institute of Technology and Evaluation, (NBRC), Kisarazu, Japan

Correspondence: Dr H Yamamura, Division of Applied Biological Sciences, Interdisciplinary Graduate School of Medicine and Engineering, University of Yamanashi, Takeda-4-4-37, Kofu 400-8510, Japan.

E-mail: hyamamura@yamanashi.ac.jp

Received 12 April 2013; revised 5 February 2014; accepted 18 February 2014; published online 2 April 2014 
While screening for plant-growth-promoting actinomycetes, we discovered strain R1-NS- $10^{\mathrm{T}}$ associated with healthy strawberry roots obtained from Hokuto City, Yamanashi Prefecture, Japan. The aim of the present study was to determine the taxonomic position of strain R1-NS-10 ${ }^{\mathrm{T}}$ using a polyphasic taxonomic approach involving chemotaxonomic, morphological, physiological, molecular and genomic characterizations as well as prediction of secondary metabolite biosynthetic gene clusters.

\section{RESULTS AND DISCUSSION}

The whole-cell hydrolysate of strain R1-NS- $10^{\mathrm{T}}$ contained LL-A 2 pm, galactose, mannose and rhamnose. The major menaquinones were MK-9 $\left(\mathrm{H}_{6}\right)(39.6 \%)$ and MK-9 $\left(\mathrm{H}_{8}\right)(60.4 \%)$. The major fatty acids $\left(>10 \%\right.$ of the total) detected in strain R1-NS-10 ${ }^{\mathrm{T}}$ were anteiso- $\mathrm{C}_{15: 0}$ $(24.6 \%)$ and iso- $\mathrm{C}_{16: 0}(22.3 \%$; Supplementary Table S1). The DNA $\mathrm{G}+\mathrm{C}$ content of strain R1-NS-10 ${ }^{\mathrm{T}}$ was $71.2 \mathrm{~mol} \%$. On the basis of the phylogenetic and chemotaxonomic findings, strain R1-NS-10 ${ }^{\mathrm{T}}$ was identified as a member of the genus Streptomyces. ${ }^{1}$

The nearly complete $16 \mathrm{~S}$ rRNA gene sequence (1493 nt) of strain R1-NS- $10^{\mathrm{T}}$ was compared with sequences of known bacterial species using the EzTaxon server. ${ }^{17}$ The results of these comparisons showed that this strain had the highest sequence similarity (99.4\%) to S. prunicolor NRRL B-12281 ${ }^{\mathrm{T}}$, followed by S. resistomycificus NBRC $12814^{\mathrm{T}}(98.6 \%)$, S. phaeoluteigriseus NRRL ISP-5182 ${ }^{\mathrm{T}}(98.6 \%)$ and S. bobili JCM $4624^{\mathrm{T}}(98.6 \%)$. The phylogenetic tree constructed with $16 \mathrm{~S}$ rRNA gene sequence data using the neighbor-joining method showed that strain R1-NS- $10^{\mathrm{T}}$ formed a monophyletic clade with $S$. prunicolor, and this result was in agreement with those obtained using the maximum-parsimony and maximum-likelihood methods (Figure 1). Further characterizations of strain R1-NS-10 ${ }^{\mathrm{T}}$ were conducted using $S$. prunicolor as the closest phylogenetic relative.

Strain R1-NS- $10^{\mathrm{T}}$ formed extensively branched substrate mycelia, and the aerial mycelia formed straight spore chains. Scanning electron microscopy showed that the spore surface was smooth and elliptical in shape and about $1.5 \mu \mathrm{m}$ long (Figure 2). The growth characteristics of strain R1-NS- $10^{\mathrm{T}}$ cultured on different media are shown in Table 1. The differential growth characteristics of strains R1-NS- $10^{\mathrm{T}}$ and S. prunicolor NBRC $13075^{\mathrm{T}}$ are shown in Table 2 and Supplementary Table S2. Soluble pigment was observed when cells were cultured on ISP-3 and ISP-5 but not when cultured on TSA, ISP-2, ISP-4, ISP-6

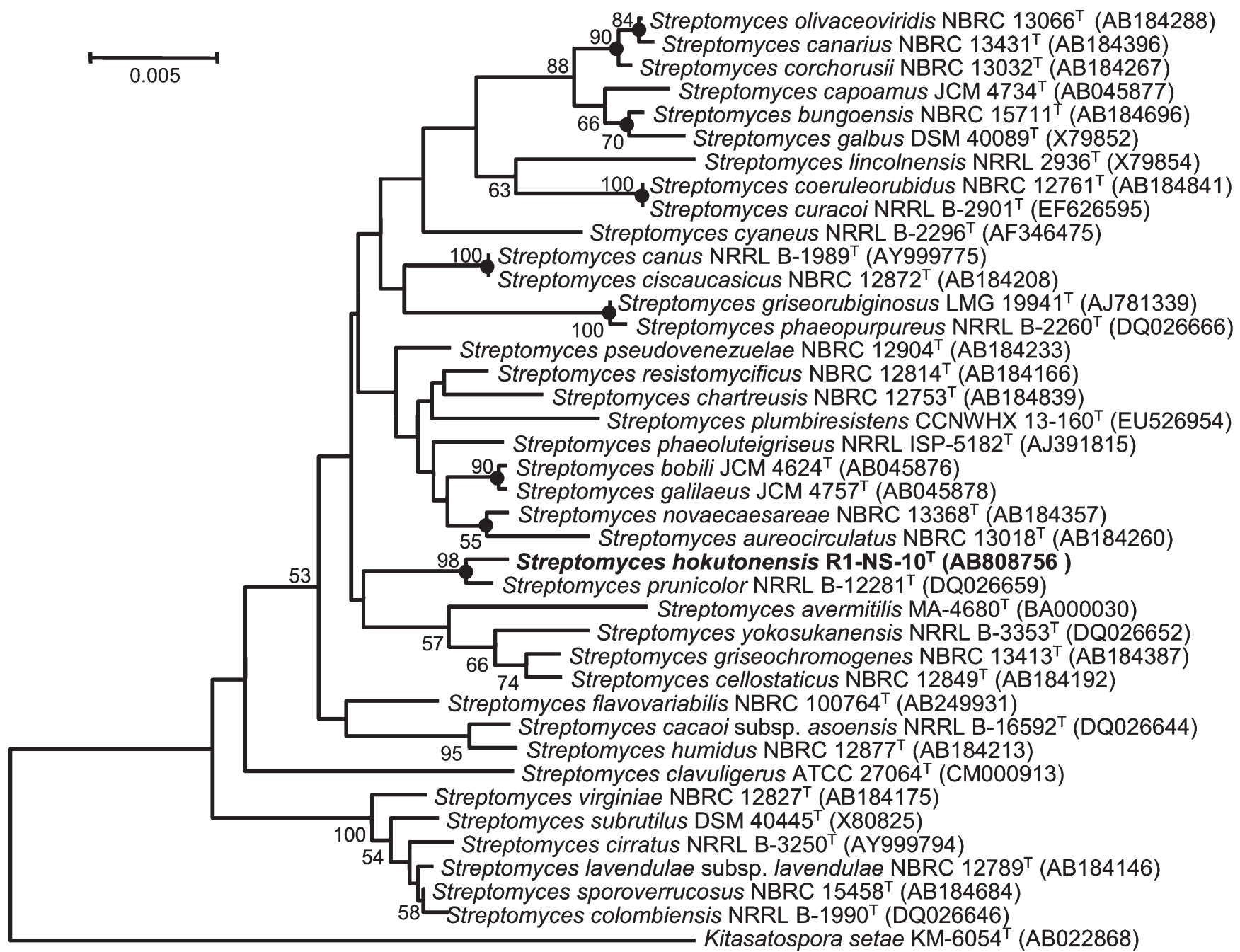

Figure 1 Phylogenetic tree derived from $16 \mathrm{~S}$ rRNA gene sequences showing the relationship between strain R1-NS-10 ${ }^{\top}$ and its phylogenetic relatives. The root position of the neighbor-joining tree was determined using Kitasatospora setae KM-6054 ${ }^{\top}$ (AB022868) as the outgroup. The tree was constructed using the neighbor-joining method and $K_{\text {nuc }}$ values. ${ }^{43}$ Only bootstrap values above $50 \%$ are shown (1000 resamplings) at the branching points. Solid circles indicate that corresponding nodes were also recovered in analyses using the maximum-parsimony and maximum-likelihood algorithms. ${ }^{44}$ Bar, $0.005 K_{\text {nuc }}$. 
and ISP-7. Melanin production was negative on ISP-6 and ISP-7 media. Strain R1-NS- $10^{\mathrm{T}}$ grew in the $\mathrm{pH}$ range 5-9 and in the presence of $0-5 \% \mathrm{NaCl}(\mathrm{w} / \mathrm{v})$, with optimal growth occurring at $\mathrm{pH} 7$ and $0 \% \mathrm{NaCl}(\mathrm{w} / \mathrm{v})$. The temperature range for growth was $5-37^{\circ} \mathrm{C}$, with an optimum of $30^{\circ} \mathrm{C}$. Strain R1-NS-10 ${ }^{\mathrm{T}}$ was easily differentiated from $S$. prunicolor by its growth characteristics on ISP media, its $\mathrm{pH}-$, temperature- and $\mathrm{NaCl}$ tolerance, $\beta$-glucosidase activity and utilization of D-mannitol, sucrose and inositol (Table 2 and Supplementary Table S3). Before the emergence of molecular taxonomy approaches, simple diagnostic keys such as morphology and phenotypic characterizations were used for streptomycete systematics. However, the use of simple identification keys alone cannot provide adequate identification compared with polyphasic taxonomy. Kämpfer et al. ${ }^{18}$ suggested that descriptions of Streptomyces species should be based on a combination of genotypic and phenotypic data.

In addition to the biologically interesting aspects of strain R1-NS- $10^{\mathrm{T}}$ as a plant-control agent (evidenced by the production of indole-3-acetic acid), the strain also exhibited antimicrobial activity against to Aspergillus niger ATCC 9642, Bacillus subtilis NBRC 3134, Saccharomyces cerevisiae NBRC $10217^{\mathrm{T}}$, Staphylococcus aureus NBRC 3061 and Pythium aphanidermatum NBRC 32440. Comprehensive genome mining employing the antiSMASH secondary metabolite identification pipeline identified 19 candidate gene clusters in strain R1-NS- $10^{\mathrm{T}}$ and S. prunicolor NBRC $13075^{\mathrm{T}}$ (Table 3). Although it is difficult to accurately determine the structure of a metabolite using

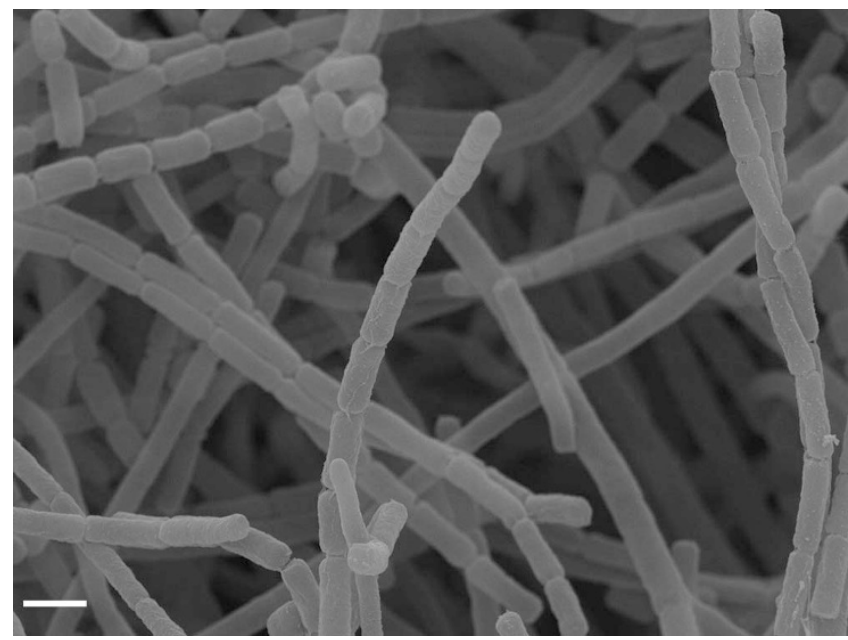

Figure 2 Scanning electron micrograph of strain R1-NS-10 ${ }^{\top}$ cultured on HA agar for 2 weeks at $30^{\circ} \mathrm{C}$. Bar indicates $1 \mu \mathrm{m}$. only genomic information, the above bioassay data suggest that strain R1-NS- $10^{\mathrm{T}}$ produces antibacterial and antifungal molecules.

The results of phylogenetic analysis of the 16S rRNA gene in the present study indicate that strain R1-NS- $10^{\mathrm{T}}$ is closely related to S. prunicolor NBRC $13075^{\mathrm{T}}$. Sequencing of the $16 \mathrm{~S}$ rRNA gene is widely used for primary molecular identification of prokaryotes. ${ }^{1,13}$ However, in the case of Streptomyces, the resolving power of $16 \mathrm{~S}$ rRNA gene sequencing is not sufficient for discrimination at the species level. Several researchers have therefore proposed the use of multilocus sequence analysis, ${ }^{19-21}$ which provides intermediate resolution' of $16 \mathrm{~S}$ rRNA gene sequences, and the use of genomebased approaches such as DDH and ANI. Here, we demonstrated the utility of genomic analyses for species-level identification by employing DDH analysis and calculation of ANI values. The DNADNA relatedness value between strain R1-NS-10 ${ }^{\mathrm{T}}$ and S. prunicolor NBRC $13075^{\mathrm{T}}$ was $52.9 \pm 3.1 \%$ (reciprocal reaction $=41.2 \pm 2.6 \%$ ), which is below the $70 \%$ cutoff point recommended for the assignment of bacterial strains to the same genomic species. ${ }^{22}$ Table 4 shows the ANIb values for strains R1-NS- $10^{\mathrm{T}}$, S. prunicolor NBRC $13075^{\mathrm{T}}$ and other Streptomyces species. These data were well below the ANI species threshold (95-96\% ANI value). ${ }^{11}$

On the basis of its phenotypic and genotypic characteristics, strain R1-NS-10 ${ }^{\mathrm{T}}$ represents a novel species within the genus Streptomyces, for which the name Streptomyces hokutonensis sp. nov. is proposed.

\section{Description of Streptomyces hokutonensis sp. nov.}

Streptomyces hokutonensis (ho.ku.to.nen'sis, N.L. masc. adj. hokutonensis, pertaining to Hokuto City, Yamanashi Prefecture, Japan, where the organism was originally isolated).

Cells are aerobic and Gram-positive. The substrate mycelia are wellbranched, and aerial mycelia fragment into long straight chains of smooth-surfaced cylindrical spores. The spores and aerial mycelia are brownish-white in color, and substrate mycelia are grayish-brown when cells are cultured on ISP-2 medium. Soluble pigment is observed on ISP-3 and ISP-5; however, the strain does not produce melanin on ISP-6 and ISP-7 media. Whole-cell hydrolysates contain $\mathrm{A}_{2} \mathrm{pm}$, galactose, mannose and rhamnose. The major fatty acids $\left(>10 \%\right.$ of total) are anteiso- $\mathrm{C}_{15: 0}$ and iso- $\mathrm{C}_{16: 0}$. MK-9 $\left(\mathrm{H}_{6}\right)$ and MK$9\left(\mathrm{H}_{8}\right)$ are the major menaquinones. The organism grows at $5-37^{\circ} \mathrm{C}$ (but not at $45^{\circ} \mathrm{C}$ ), in the presence of $0-5 \% \mathrm{NaCl}(\mathrm{w} / \mathrm{v})$, and at an initial $\mathrm{pH}$ of 5-9. Optimal growth conditions are $30^{\circ} \mathrm{C}, \mathrm{pH} 7$ and $0 \%$ $\mathrm{NaCl}$. Nitrate is not reduced and the catalase reaction is positive. Starch is hydrolyzed. D-Glucose, D-fructose, D-galactose, D-maltose, D-mannose, D-trehalose, D-raffinose, D-xylose, L-arabinose, glycerol and L-rhamnose are utilized as sole carbon sources; however,

Table 1 Characteristics of strain R1-NS-10 $0^{\top}$ cultured on various media

Color of mycelium

\begin{tabular}{llll} 
Medium & Growth & Soluble pigment & Aerial \\
\hline Yeast extract-malt extract agar (ISP 2) & +++ & None & Brownish-white \\
Oatmeal agar (ISP 3) & +++ & Yellow & Pale brown \\
Inorganic salts-starch agar (ISP 4) & +++ & None & Light brownish gray \\
Glycerol/asparagine agar (ISP 5) & +++ & Brown & Pale orange \\
Peptone-yeast extract-iron agar (ISP 6) & + & None & None \\
Tyrosine agar (ISP 7) & +++ & None & Pale yellowish brown \\
Trypticase soy agar (TSA) & + & Reddish-brown & Pale yellow \\
\hline
\end{tabular}

Abbreviations: ISP, International Streptomyces Project; + , poor growth; +++ , abundant growth.

All media were adjusted to $\mathrm{pH}$ 7.0. 
Table 2 Differential characteristics of strain R1-NS-10 ${ }^{\top}$ and S. prunicolor NBRC $13075^{\top}$

\begin{tabular}{|c|c|c|}
\hline Characteristic & 1 & 2 \\
\hline \multicolumn{3}{|l|}{ Characteristics on ISP3 } \\
\hline Soluble pigment production & + & - \\
\hline Aerial mycelium & Pale brown & Grayish-white \\
\hline Color of substrate mycelium & Light brown & Pale yellow \\
\hline $\mathrm{pH}$ range & $5-9$ & $5-8$ \\
\hline Temperature range for growth $(\mathrm{C})$ & $5-37$ & 20-37 \\
\hline $\mathrm{NaCl}$ tolerance $(\%, \mathrm{w} / \mathrm{v})$ & 5 & 3 \\
\hline \multicolumn{3}{|l|}{$A P I Z Y M$} \\
\hline$\beta$-glucosidase & + & - \\
\hline \multicolumn{3}{|l|}{ Utilization of sole $C$-source } \\
\hline D-mannitol & - & + \\
\hline Sucrose & - & + \\
\hline Inositol & - & + \\
\hline \multicolumn{3}{|c|}{$\begin{array}{l}\text { Strains: } 1, \text { S. hokutonensis R1-NS-10'; } 2, \text { S. prunicolor NBRC } 13075^{\top} ;(+) \text {, positive; }(-) \text {, } \\
\text { negative. } \\
\text { All data were generated in the present study. } \\
\text { Both strains were positive for alkaline phosphatase, esterase (C4), leucine arylamidase, valine } \\
\text { arylamidase, trypsin, acid phosphatase, naphthol-AS-BI-phosphohydrolase, } \alpha \text {-galactosidase, } \\
\beta \text {-galactosidase, } \alpha \text {-glucosidase, } N \text {-acetyl- } \beta \text {-glucosaminidase, } \alpha \text {-mannosidase and hydrolysis of } \\
\text { starch, and utilization of D-glucose, D-galactose, D-mannose, D-raffinose, D-xylose, L-arabinose, } \\
\text { glycerol and L-rhamnose. Both strains were negative for lipase (C14), cystine arylamidase, } \\
\alpha \text {-chymotrypsin, } \beta \text {-glucuronidase, } \alpha \text {-fucosidase and utilization of D-sorbitol, D-turanose and } \\
\text { L-arabitol. }\end{array}$} \\
\hline
\end{tabular}

D-mannitol, D-sorbitol, D-sucrose, inositol, D-turanose and L-arabitol are not utilized as sole carbon sources. API ZYM tests for alkaline phosphatase, esterase (C4), leucine arylamidase, valine arylamidase, trypsin, acid phosphatase, naphthol-AS-BI-phosphohydrolase, $\alpha$-galactosidase, $\beta$-galactosidase, $\alpha$-glucosidase, $\beta$-glucosidase, $N$-acetyl- $\beta$-glucosaminidase and $\alpha$-mannosidase activity are positive. The test for esterase lipase (C8) is weakly positive. Tests for lipase (C14), cystine arylamidase, $\alpha$-chymotrypsin, $\beta$-glucuronidase and $\alpha$-fucosidase activity are negative. The DNA G $+C$ content of the type strain is $71.2 \mathrm{~mol} \%$.

The type strain is R1-NS $-10^{\mathrm{T}}\left(=\mathrm{NBRC} 108812^{\mathrm{T}}=\mathrm{KCTC} 29186^{\mathrm{T}}\right)$ and was isolated from a sample of strawberry roots obtained from Hokuto City, Yamanashi, Japan.

\section{MATERIALS AND METHODS}

\section{Isolation and maintenance of the organism}

A sample of healthy strawberry root was collected in an agricultural field in Hokuto City, Yamanashi, Japan. Although the root sample $(1 \mathrm{~g})$ was washed with sterilized water $(500 \mathrm{ml})$ to remove most of the associated soil particles, a small amount of soil remained attached. The root was then homogenized in sterilized distilled water using a mortar and pestle. The resulting suspension $(0.2 \mathrm{ml})$ was spread onto humic acid-vitamin (HV) $\operatorname{agar}^{23}$ containing nalidixic acid $\left(20 \mathrm{mgl}^{-1}\right)$ and cycloheximide $\left(50 \mathrm{mgl}^{-1}\right)$ and then incubated at $30^{\circ} \mathrm{C}$ for 2 weeks. Following the incubation period, strain R1-NS- $10^{\mathrm{T}}$ was isolated and transferred to oatmeal-YGG agar. ${ }^{24}$ The organism was also preserved in $20 \%(\mathrm{v} / \mathrm{v})$ glycerol at $-80^{\circ} \mathrm{C}$.

\section{Phenotypic characterization}

Strain R1-NS- $10^{\mathrm{T}}$ was grown on HA agar ${ }^{25}$ for 14 days at $28^{\circ} \mathrm{C}$, and its morphological features were analyzed using both light microscopy and scanning electron microscopy (JEOL, JSM-6500F). The aerial mycelium, substrate mycelium and pigmentation colors of strain R1-NS- $10^{\mathrm{T}}$ were recorded for cells cultured on ISP (International Streptomyces Project) media $^{26}$ and tryptic soy agar (TSA) (Bacto). The Guide to Color Standard (Japan Color Research Institute 1954) was used for color determination.
Table 3 Number of predicted secondary metabolite biosynthetic gene clusters in the genome of strain R1-NS-10 ${ }^{\top}$ and $S$. prunicolor NBRC $13075^{\top}$, as determined using the antiSMASH 2.0 software $^{46}$

\begin{tabular}{|c|c|c|}
\hline Type of gene or cluster & 1 & 2 \\
\hline Polyketides (type I) & 3 & 3 \\
\hline Polyketides (type II) & 1 & 1 \\
\hline Polyketides (type III) & 1 & 1 \\
\hline Polyketides (type IV) & 0 & 2 \\
\hline Nonribosomal peptides & 8 & 6 \\
\hline Terpenes & 4 & 6 \\
\hline Lantibiotics & 0 & 0 \\
\hline Lantipeptide & 1 & 1 \\
\hline Bacteriocins & 3 & 6 \\
\hline Siderophores & 3 & 3 \\
\hline Ectoines & 1 & 1 \\
\hline Butyrolactones & 1 & 1 \\
\hline Nucleosides & 0 & 1 \\
\hline Melanins & 1 & 0 \\
\hline Transatpks-t1pks-t2pks & 0 & 1 \\
\hline T4pks-t1pks & 0 & 1 \\
\hline Phosphonate & 1 & 0 \\
\hline Oligosaccharide-t1pks-t4pks & 1 & 0 \\
\hline Nrps-melanin & 1 & 0 \\
\hline Other & 4 & 3 \\
\hline Total & 19 & 19 \\
\hline
\end{tabular}

Strains: 1 , S. hokutonensis R1-NS-10 ${ }^{\top} ; 2$, S. prunicolor NBRC $13075^{\top}$.

Table 4 ANIb values calculated using the JSpecies software. ${ }^{11}$

\begin{tabular}{lccccc}
\hline & \multicolumn{5}{c}{ Target genome } \\
\cline { 2 - 6 } Query genome & 1 & 2 & 3 & 4 & 5 \\
\hline S. hokutonensis R1-NS-10 & - & 82.4 & 80.1 & 81.4 & 76.5 \\
S. prunicolor NBRC 13075' & 82.6 & - & 80.0 & 81.4 & 76.2 \\
\hline
\end{tabular}

Strains: 1, S. hokutonensis R1-NS-10 (BARG01000001-BARG01000178); 2, S. prunicolor NBRC $13075^{\top}$ (BARF01000001-BARF01000202); 3, S. coelicolor A3(2) (uid57801); 4 ,

S. avermitilis MA 4680 (uid57739); 5, S. griseus NBRC 13350 (uid58983).

Cells were Gram-stained according to the method of Hucker. ${ }^{27}$ To determine the optimal growth temperature, strain R1-NS-10 ${ }^{\mathrm{T}}$ was incubated for 7 and 14 days on oatmeal-YGG agar at temperatures of $5,10,20,30,37,40$ and $45^{\circ} \mathrm{C}$. Growth at 5 and $10^{\circ} \mathrm{C}$ was assayed after 6 weeks of incubation. Growth at $\mathrm{pH}$ values ranging from 5 to 11 (in $1 \mathrm{pH}$ unit increments) and in the presence of various concentrations of $\mathrm{NaCl}(0-8 \%(\mathrm{w} / \mathrm{v})$, in $1 \%$ increments) was evaluated after 14 and 21 days of incubation on ISP- 2 medium. ${ }^{26}$ Melanin production was assessed after 1-4 days of growth on ISP-6 and ISP-7 media. ${ }^{26}$ Carbonsource utilization was examined using ISP-9 as a basal medium. Antimicrobial activity was assayed using an overlay method ${ }^{28}$ against 19 microorganisms: Aspergillus niger ATCC 9642, Botryotinia fuckeliana NBRC 30915, Bacillus subtilis NBRC 3134, Candida albicans NBRC $1385^{\mathrm{T}}$, Cercospora kikuchii NBRC 6711, Clavibacter michiganensis subsp. michiganensis NBRC 13762, Colletotrichum orbiculare NBRC 33130, Escherichia coli NBRC 3044, Fusarium oxysporum NBRC 31213, Fusarium solani NBRC 9955, Pythium aphanidermatum NBRC 32440, Pythium helicoids NBRC 100107, Rhizobium rhizogenes NBRC $13257^{\mathrm{T}}$, Rhizobium rubi NBRC $13261^{\mathrm{T}}$, Saccharomyces cerevisiae NBRC $10217^{\mathrm{T}}$, Staphylococcus aureus NBRC 3061, Streptomyces scabiei NBRC 12914, Streptomyces turgidiscabies NBRC $16080^{\mathrm{T}}$ and Thanatephorus cucumeris NBRC 30455. Briefly, spot-inoculated, 10-day-old colonies of strain R1-NS- $10^{\mathrm{T}}$ cultured on nutrient agar plates were overlaid with $5 \mathrm{ml}$ of sloppy nutrient agar /YEPD agar inoculated with the test organism. The size of the zone of inhibition around each colony was recorded after incubation for $24 \mathrm{~h}$ at $30^{\circ} \mathrm{C}$. Production of indole-3-acetic 
acid by strain R1-NS- $10^{\mathrm{T}}$ was determined according to the method of Matsukawa et al..$^{29,30}$ and use of Salkowski reagent.

\section{Chemotaxonomy}

Cell biomass was hervested for chemotaxonomic studies by incubating strain R1-NS- $10^{\mathrm{T}}$ in yeast extract-glucose (YG) broth for $5-7$ days at $30^{\circ} \mathrm{C}$ with shaking. ${ }^{31}$ Cells were harvested by centrifugation and the resulting pellet was washed twice with distilled water. $\mathrm{A}_{2} \mathrm{pm}$ isomers and sugars in whole-cell hydrolysates were analyzed based on the methods described by Hasegawa et al. ${ }^{32}$ and Tamura et al., ${ }^{33}$ respectively. Cellular fatty acids were processed and analyzed as methyl esters following the protocol for the MIDI Sherlock Microbial Identification System. ${ }^{34}$ Isoprenoid quinones were extracted and isolated using standard procedures, ${ }^{35}$ with the results compared to those of appropriate controls. The isoprenoid quinone content was determined using liquid chromatography/mass spectrometry (LC/MS), as described by Hamada et al. ${ }^{36}$ The DNA G + C content of strain R1-NS- $10^{\mathrm{T}}$ was determined by HPLC as described by Tamaoka and Komagata. ${ }^{37}$

\section{Molecular analysis}

Chromosomal DNA was isolated from strain R1-NS- $10^{\mathrm{T}}$ and purified as described by Saito and Miura, ${ }^{38}$ with a minor modification. ${ }^{39}$ The $16 \mathrm{~S}$ rRNA gene from strain R1-NS- $10^{\mathrm{T}}$ was amplified by PCR as described by Tamura and Hatano, ${ }^{40}$ and the PCR product was purified using a MonoFas DNA Purification Kit (GL Sciences, Tokyo, Japan). The purified PCR product was directly sequenced using an ABI Prism BigDye Terminator Cycle Sequencing Kit (Applied Biosystems, Foster City, CA, USA) and a Model 3730 Genetic Analyzer automated DNA sequencer (Applied Biosystems). The 16S rRNA gene sequence was compared with published 16S rRNA gene sequences of bacterial type strains using the EzTaxon server (http://www.eztaxon.org/). ${ }^{17}$ For phylogenetic analyses, 16S rRNA gene sequences were collected from the EMBL/GenBank/DDBJ databases and aligned using the CLUSTAL_X program. ${ }^{41}$ Phylogenetic trees were constructed using the Molecular Evolutionary Genetics Analysis software, version 5.1, ${ }^{42}$ with the neighborjoining, maximum parsimony and maximum-likelihood methods. ${ }^{43,44}$ The topologies of the constructed trees were evaluated by bootstrap analysis with 1000 resamplings. ${ }^{45}$ The online web server antiSMASH 2.0 (antibiotics \& Secondary Metabolites Analysis SHell) was used to predict secondary metabolite biosynthetic gene clusters in the genomes of strain R1-NS- $10^{\mathrm{T}}$ and S. prunicolor NBRC $13075^{\mathrm{T}} .^{46}$

\section{DDH and ANIb calculation}

DDH analyses were carried out as described by Kusunoki et al. ${ }^{47}$ using biotinylated DNA, with five replications for each sample. The highest and lowest values obtained for each sample were excluded, and the mean of the remaining three values was reported as the DNA-DNA relatedness value. Random partial genome pyrosequencing analyses were performed using strains R1-NS- $10^{\mathrm{T}}$ and S. prunicolor NBRC $13075^{\mathrm{T}}$. The genome sequence was examined using a combined strategy involving GS FLX Titanium and HiSeq 1000 technologies. Two different libraries were constructed for sequencing: a standard library (600-900 bp) for the GS FLX Titanium strategy and a paired ends (200-500 bp insert) library for the HiSeq 1000 strategy. Sequences were assembled using the Newbler v2.6 software (Roche Applied Science, Branford, CT, USA) with the default parameters. The ANI by BLAST value was calculated using the JSpecies program with default settings. ${ }^{10,11}$ JSpecies was primarily designed to analyze and compare innerspecies boundaries between genomes, draft genomes or partial random genome sequences.

\section{Nucleotide and genome sequence accession numbers}

The 16S rRNA gene sequence of strain R1-NS- $10^{\mathrm{T}}$ determined in this study has been deposited in the DDBJ database under the accession number AB808756. The draft genome sequences of strain R1-NS- $10^{\mathrm{T}}$ and S. prunicolor NBRC $13075^{\mathrm{T}}$ were deposited in the DDBJ/EMBL/GenBank databases under the accession numbers BARG01000001-BARG01000178 and BARF01000001BARF01000202, respectively.

\section{ACKNOWLEDGEMENTS}

This work was conducted and supported under the joint research project 'Locally produced and Consumed' between the Ministry of Education, Culture, Sports, Science and Technology (MEXT), Hokuto City and the University of Yamanashi. This study was supported in part by a research grant from the Institute for Fermentation, Osaka (IFO), Japan. We are grateful to Dr Jean P Euzéby for assistance with nomenclature.

1 Kämpfer, P. \& Genus, I. in Bergey's Manual of Systematic Bacteriology. 2nd edn Vol. 3 (eds Goodfellow, M. et al.) 1455-1767 (Springer, USA, 2012).

2 Euzéby, J. P. List of Prokaryotic names with Standing in Nomenclature http:// www. bacterio.cict.fr/ (2013)

3 Bérdy, J. Thoughts and facts about antibiotics: where we are now and where we are heading. J. Antibiot. 65, 385-395 (2012).

4 Kino, T. et al. FK-506, a novel immunosuppressant isolated from a Streptomyces. I. Fermentation, isolation, and physico-chemical characteristics. J. Antibiot. 40, 1249-1255 (1987).

5 Burg, R. W. et al. Avermectins, new family of potent anthelmintic agents: producing organism and fermentation. Antimicrob. Agents Chemother. 15, 361-367 (1979).

6 Hata, T. et al. Mitomycin, a new antibiotic from Streptomyces. I. J. Antibiot. 9, 141-146 (1956)

7 Bentley, S. D. et al. Complete genome sequence of the model actinomycete Streptomyces coelicolor A3(2). Nature 417, 141-147 (2002).

8 Ikeda, H. et al. Complete genome sequence and comparative analysis of the industrial microorganism Streptomyces avermitilis. Nat. Biotechnol. 21, 526-531 (2003).

9 Ohnishi, Y. et al. Genome sequence of the streptomycin-producing a microorganism Streptomyces griseus IFO 13350. J. Bacteriol. 190, 4050-4060 (2008).

10 Goris, J. et al. DNA-DNA hybridization values and their relationship to whole- genome sequence similarities. Int. J. Syst. Evol. Microbiol. 57, 81-91 (2007).

11 Richter, M. \& Rosselló-Móra, R. Shifting the genomic gold standard for the prokaryotic species definition. Proc. Natl Acad. Sci. USA 106, 19126-19131 (2009).

12 Konstantinidis, K. T. \& Tiedje, J. M. Prokaryotic taxonomy and phylogeny in the genomic era: advancements and challenges ahead. Curr. Opin. Microbiol. 10, 504-509 (2007).

13 Kämpfer, P. in The family Streptomycetaceae. Part I. Taxonomy. in The Prokaryotes: A Handbook on the Biology of Bacteria. 3rd edn Vol. 3 (eds Dworkin, M., Falkow, S., Rosenberg, E., Schleifer, K. H. \& Stackebrandt, E.) 538-604 (Springer, New York, 2006).

14 González, I., Ayuso-Sacido, A., Anderson, A. \& Genilloud, O. Actinomycetes isolated from lichens: evaluation of their diversity and detection of biosynthetic gene sequences. FEMS Microbiol. Ecol. 54, 401-415 (2005)

15 De Vasconcellos, R. L. F. \& Cardoso, E. J. B. N. Rhizospheric streptomycetes as potential biocontrol agents of Fusarium and Armillaria pine rot and as PGPR for Pinus taeda. BioControl 54, 807-816 (2009).

16 Sadeghi, A. et al. Plant growth promoting activity of an auxin and siderophore producing isolate of Streptomyces under saline soil conditions. World J. Microbiol. Biotechnol. 28, 1503-1509 (2012).

17 Chun, J. et al. EzTaxon: a web-based tool for the identification of prokaryotes based on 16S ribosomal RNA gene sequences. Int. J. Syst. Evol. Microbiol. 57, 2259-2261 (2007).

18 Kämpfer, P., Huber, B., Buczolits, S., Thummes, K., Grün-Wollny, I. \& Busse, H. J. Streptomyces specialis sp. nov. Int. J. Syst. Evol. Microbiol. 58, 2602-2606 (2008).

19 Guo, Y., Zheng, W., Rong, X. \& Huang, Y. A multilocus phylogeny of the Streptomyces griseus 16S rRNA gene clade: use of multilocus sequence analysis for streptomycete systematics. Int. J. Syst. Evol. Microbiol. 58, 149-159 (2008).

20 Labeda, D. P. Multilocus sequence analysis of phytopathogenic species of the genus Streptomyces. Int. J. Syst. Evol. Microbiol. 61, 2525-2531 (2011).

21 Rong, X. \& Huang, Y. Taxonomic evaluation of the Streptomyces hygroscopicus clade using multilocus sequence analysis and DNA-DNA hybridization, validating the MLSA scheme for systematics of the whole genus. Syst. Appl. Microbiol. 35, 7-18 (2012).

22 Wayne, L. G. et al. Report of the ad hoc committee on reconciliation of approaches to bacterial systematics. Int. J. Syst. Bacteriol. 37, 463-464 (1987).

23 Hayakawa, M. \& Nonomura, H. Humic acid-vitamin agar, a new medium for the selective isolation of soil actinomycetes. J. Ferment. Technol. 65, 501-509 (1987).

24 Hayakawa, M., lino, S. \& Nonomura, H. Heavy metal resistance and melanoid pigment production in the streptomycete flora of copper-polluted vineyard soils. J. Ferment. Technol. 60, 1-9 (1982).

25 Nonomura, H., lino, S. \& Hayakawa, M. Classification of actinomycete genus Ampullariella from soils of Japan. J. Ferment. Technol. 57, 79-85 (1979).

26 Shirling, E. B. \& Gottlieb, D. Methods for characterization of Streptomyces species. Int. J. Syst. Bacteriol. 16, 313-340 (1966).

27 Gerhardt, P. Manual of Methods for General Bacteriology (American Society for Microbiology, Washington, DC, 1981).

28 Williams, S. T. et al. Numerical classification of Streptomyces and related taxa. J. Gen. Microbiol. 129, 1743-1813 (1983).

29 Matsukawa, E., Nakagawa, Y., limura, Y. \& Hayakawa, M. Stimulatory effect of indole3 -acetic acid on aerial mycelium formation and antibiotic production in Streptomyces spp. Actinomycetol. 21, 32-39 (2007) 
30 Gordon, S. A. \& Weber, R. P. Colorimetric estimation of indoleacetic acid. Plant. Physiol. 26, 192-195 (1951).

31 Gordon, R. E. \& Mihm, J. M. Identification of Nocardia caviae (Erikson) nov. comb. Ann. N. Y. Acad. Sci. 98, 628-636 (1962).

32 Hasegawa, T., Takizawa, M. \& Tanida, S. A rapid analysis for chemical grouping of aerobic actinomycetes. J. Gen. Appl. Microbiol. 29, 319-322 (1983).

33 Tamura, T., Ishida, Y. \& Suzuki, K-I. Descriptions of Actinoplanes ianthinogenes nom. rev. and Actinoplanes octamycinicus corrig. comb. nov., nom. rev. Int. J. Syst. Evol. Microbiol. 61, 2916-2921 (2011).

34 Sasser, M. Identification of Bacteria by Gas Chromatography of Cellular Fatty Acids (Microbial ID, Inc., Newark, Delaware, 1990).

35 Minnikin, D. E. et al. An integrated procedure for the extraction of bacterial isoprenoid quinines and polar lipids. J. Microbiol. Methods 2, 233-241 (1984).

36 Hamada, M., Iino, T., Iwami, T., Harayama, S., Tamura, T. \& Suzuki, K. Mobilicoccus pelagius gen. nov., sp. nov. and Piscicoccus intestinalis gen. nov., sp. nov., two new members of the family Dermatophilaceae, and reclassification of Dermatophilus chelonae (Masters et al. 1995) as Austwickia chelonae gen. nov., comb. nov. J. Gen. Appl. Microbiol. 56, 427-436 (2010).

37 Tamaoka, J. \& Komagata, K. Determination of DNA base composition by reversedphase high-performance liquid chromatography. FEMS Microbiol. Lett. 25, 125-128 (1984).

38 Saito, H. \& Miura, K.-I. Preparation of transforming deoxyribonucleic acid by phenol treatment. Biochim. Biophys. Acta 72, 619-629 (1963).

39 Hatano, K., Nishii, T. \& Kasai, H. Taxonomic re-evaluation of whorl-forming Streptomyces (formerly Streptoverticillium) species by using phenotypes, DNA-DNA hybridization and sequences of gyrB, and proposal of Streptomyces luteireticuli (ex Katoh and Arai 1957) corrig., sp. nov., nom. rev. Int. J. Syst. Evol. Microbiol. 53, 1519-1529 (2003)

40 Tamura, T. \& Hatano, K. Phylogenetic analysis of the genus Actinoplanes and transfer of Actinoplanes minutisporangius Ruan et al. 1986 and 'Actinoplanes aurantiacus' to Cryptosporangium minutisporangium comb. nov. and Cryptosporangium aurantiacum sp. nov. Int. J. Syst. Evol. Microbiol. 51, 2119-2125 (2001).

41 Thompson, J. D., Gibson, T. J., Plewniak, F., Jeanmougin, F. \& Higgins, D. G. The CLUSTAL_X Windows interface: flexible strategies for multiple sequence alignment aided by quality analysis tools. Nucleic Acids Res. 25, 4876-4882 (1997).

42 Tamura, K., Peterson, D., Peterson, N., Stecher, G., Nei, M. \& Kumar, S. MEGA5: Molecular evolutionary genetics analysis using maximum likelihood, evolutionary distance, and maximum parsimony methods. Mol. Biol. Evol. 28, 2731-2739 (2011).

43 Saitou, N. \& Nei, M. The neighbor-joining method: a new method for reconstructing phylogenetic trees. Mol. Biol. Evol. 4, 406-425 (1987).

44 Takahashi, K. \& Nei, M. Efficiencies of fast algorithms of phylogenetic inference under the criteria of maximum parsimony, minimum evolution, and maximum likelihood when a large number of sequences are used. Mol. Biol. Evol. 17, 1251-1258 (2000).

45 Felsenstein, J. Confidence limits on phylogenies: an approach using the bootstrap. Evolution 39, 783-791 (1985).

46 Blin, K. et al. antiSMASH 2.0-a versatile platform for genome mining of secondary metabolite producers. Nucleic Acids Res. 41, W204-W212 (2013).

47 Kusunoki, S. et al. Application of colorimetric microdilution plate hybridization for rapid genetic identification of 22 Mycobacterium species. J. Clin. Microbiol. 29, 1596-1603 (1991).

Supplementary Information accompanies the paper on The Journal of Antibiotics website (http://www.nature.com/ja) 